DOI: https://doi.org/10.34069/AI/2022.49.01.13

How to Cite:

Latkovskyi, P., Demchuk, T., Veselyi, V., Shliakhov, I., \& Manchul, M.D. (2022). Social policy in Ukraine during the Covid-19 pandemic and its impact on public finance. Amazonia Investiga, 11(49), 117-125. https://doi.org/10.34069/AI/2022.49.01.13

\title{
Social policy in Ukraine during the Covid-19 pandemic and its impact on public finance
}

\section{Соціальна політика в Україні під час пандемії Covid-19 та її вплив на публічні фінанси}

Received: November 25, 2021

Accepted: January 15, 2022

\author{
Written by: \\ Latkovskyi Pavlo ${ }^{48}$ \\ https://orcid.org/0000-0002-2406-766X \\ Demchuk Tetiana ${ }^{49}$ \\ https://orcid.org/0000-0002-0955-1816 \\ Veselyi Vladyslav ${ }^{50}$ \\ https://orcid.org/0000-0002-0315-641X \\ Shliakhov Illia ${ }^{51}$ \\ https://orcid.org/0000-0002-6901-211X \\ Manchul Mariia-Diana ${ }^{52}$ \\ https://orcid.org/0000-0002-7387-6236
}

\begin{abstract}
The Purpose of the article: research and analysis of social policy in Ukraine during the COVID-19 pandemic and its impact on public finances. Methodology: dialectical method of cognition of social phenomena, logical-semantic and formallogical methods, special-legal method. Conclusions and results: it is noted that an important aspect is the implementation of social policy based on distributivity, that is, competent authorities being able to conduct their activity on the basis of redistributive processes aimed at overcoming socio-economic inequality among different segments of the population. Emphasis is placed on the effectiveness of introduction of a remote form of work that enables employees to continue to perform their duties. The growing level of digitalization of public services is justified. The introduction of a range of measures to support the population and business in Ukraine since 2020 has been studied. It is found that social support of citizens in this period can be considered in two aspects, as direct and indirect. Direct social support is a set of measures taken by the government to ensure the implementation of social rights of citizens by increasing the amount of social benefits. Indirect social support
\end{abstract}

\begin{abstract}
Анотація
Мета статті: дослідження та аналіз соціальної політики в Україні під час пандемії COVID19 та пї вплив на публічні фінанси. Методологія: ділектичний метод пізнання соціальних явищ, логіко-семантичний та формально-логічний методи, спеціальноюридичний метод. Висновки та результати: у статті відзначено, що важливим аспектом $є$ здійснення соціальної політики на основі дистрибутивності, тобто провадження компетентними органами своєї діяльності на основі перерозподільчих процесів, орієнтованих на подолання соціальноекономічної нерівності серед різних верств населення. Акцентовано увагу на дієвості впровадження дистанційної форми здійснення працівниками своїх обов'язків. Обгрунтовано зростаючий рівень цифровізації державних послуг. Окреслено запровадження цілого комплексу заходів для підтримки населення та бізнесу в Україні, починаючи з 2020 року. Встановлено, що соціальну підтримку громадян у даний період можна розглядати 3 двох аспектів, як безпосередню та непряму. Безпосередня соціальна підтримка - це комплекс заходів, здійснюваних урядом для забезпечення
\end{abstract}

\footnotetext{
${ }^{48} \mathrm{PhD}$ in Laws, assistant professor, National University “Odessa Law Academy”, Ukraine.

${ }^{49} \mathrm{PhD}$ candidate, National University "Odessa Law Academy", Ukraine.

${ }^{50} \mathrm{PhD}$ candidate, National University "Odessa Law Academy", Ukraine.

${ }^{51} \mathrm{PhD}$ candidate, Taras Shevchenko National University of Kyiv, Ukraine.

${ }^{52} \mathrm{PhD}$ candidate, National University "Odessa Law Academy", Ukraine.
} 
of citizens should include measures taken by the government to curb unemployment.

Key words: social policy, home-based work, social support, social rights.

\section{Introduction}

The introduction of quarantine plunged the world economy into crisis. In all countries, there is a decline in GDP, the labour market is also under severe pressure. It is no exaggeration to say that the COVID-19 pandemic led to the greatest crisis in the field of health care, but at the same time became a litmus test that showed the existing socio-economic problems in other spheres of state and public life and created a huge challenge for the social system. Only well-developed countries, taking numerous socio-political anticrisis measures, can meet such challenges and the success of this process depends on many factors, including economic situation, appropriate legislation, adherence to fundamental human rights principles, coherence of government, timely implementation of reforms etc.

Apart from the fact that most of the actions of European governments were aimed at increasing the flexibility of infrastructure and health workers, European countries are also implementing other measures to maintain social status and stabilise the economy. These include easier access to unemployment benefits, tax benefits, soft loans, and the possibility of deferring social security contributions. In fact, there is social compensation. At the same time, local and national coronavirus control strategies in many cases increase the burden on those most in need of care.

An important aspect is the implementation of social policy based on distributivity, that is, competent authorities being able to conduct their activity based on redistributive processes aimed at overcoming socio-economic inequality among different segments of the population. In this regard, it is necessary to coordinate the two most important areas of public policy, which are budget and social. Therefore, the effectiveness of social policy directly depends on the amount of funds in the budget, and their implementation should be built in such a way as to ensure economic growth while solving social problems. реалізації соціальних прав громадян, шляхом збільшення розмірів соціальних виплат. До непрямої соціальної підтримки громадян варто віднести здійснювані урядом заходи, що здійснюються задля стримування безробіття.

Ключові слова: соціальна політика, надомна праця, соціальна підтримка, соціальні права.

It should be noted that Ukraine, for a number of objective reasons, is in a state of limited finances and cannot afford the same amount of assistance as in developed European countries, but some steps are being taken now (Holosnichenko, 2020, p. 165).

Consensus forecast "Ukraine: the impact of COVID-19 on the economy and society" (vision of post-pandemic development in 2020-2024 through the eyes of experts and youth) (UNICEF, 2020), conducted by the Department of Strategic Planning and Macroeconomic Forecasting of the Ministry of Economic Development, Trade and Agriculture shows that, according to experts, in 2022-2024 Ukraine's economic growth will accelerate. All elements of demand will also have a positive trend. Growth in investments will make $9.3 \%$ on average annually for the period. Unemployment will reach pre-pandemic level, which is $8.2 \%$, only in 2024. Ukraine will need from 1 to 2 years to restore the lost potential during the first wave of the COVID-19 pandemic.

\section{Methodology}

The choice of research methods is determined by the goal, specifics of the object, subject and objectives of the study. A systematic approach to their application allowed to conduct a comprehensive study of the principles of social policy in a pandemic, to establish the level of preparation of the state for modern challenges, to identify shortcomings in legal regulation.

The methodological basis of the study is the dialectical method of cognition of social phenomena. While conducting the study, we also used general scientific and special methods. Logical-semantic and formal-logical methods were used in streamlining the existing conceptual framework for the definition of "electronic public service". The special legal method made it possible to characterise the social policy of the state in the context of the COVID-19 pandemic as a legal phenomenon and its impact on public 


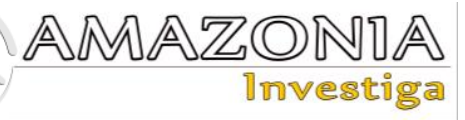

finances. The historical and legal method helped in the study of domestic legislation and its development.

\section{Literature review}

Many scientific works of domestic and foreign scientists are devoted to the study of social policy in the context of the COVID-19 pandemic. D. Holosnichenko, Y. Chuprina, N. Lukyanova and O. Zaytseva, I. Kudriavtsev, S. Silchenko and D. Serbina, N. Bukhanan, D. Aslaner, D. Burgessc and others made a significant contribution with their publications.

In his study "Social security of citizens in the context of coronavirus", D. Holosnichenko (2020) concludes that, in terms of improving the financial situation, one of the effective measures to overcome the economic crisis could be abolition of fines and penalties on loans. Another measure he points out is the introduction of repayment holidays, not only for small and medium-sized businesses, but also for ordinary consumers.

N. Lukyanova and O. Zaytseva conducted a thorough analysis in the field of legal mechanisms for the protection of labour and social rights of workers (2021). Labour rights have also been the subject of research and other scientific publications by $\mathrm{Y}$. Chuprina and several other scholars who have highlighted their scientific results in the work "Constitutional Guarantees of the Right to Work in a COVID-19 Pandemic" (Chupryna, Murtishcheva, Kravtsov, Poproshaieva, Zakomorna, 2021). Another important scientific achievement for analysis in the context of this topic was the work "Covid Pandemic and Amendments to Employment Law in Ukraine and Europe" (Kudriavtsev, Kotova and Arsentieva, 2021). Research of remote work and conclusions that deserve attention are contained in the scientific achievements "Remote Work: Current State and Prospects of the Legal Regulation Development" (Silchenko and Serbina, 2021). The positive consequences of the introduction of telecommuting have been highlighted by foreign scholars in their publications (Buchanan, Aslaner, Adelstein, MacKenzie, Wold, Gorr, 2021).

\section{Research findings}

On March 24, 2021, the European Committee of Social Rights has published a formal Statement on COVID-19 and Social Rights, which contains recommendations for current states in the light of the current world situation and calls for change in legislation, policy implementation and resource allocation in the coming years. The Statement on COVID-19 and social rights was based on the 1989 European Social Charter, which was ratified by Ukraine in 2006.

Investing in social rights is of paramount importance when it comes to coping with and recovering from the COVID-19 pandemic. The member states of the European Social Charter must take all necessary measures, including the redistribution of resources, to combat the virus and ensure the rights of their populations, particularly the most vulnerable groups. If necessary, this will require States parties to take positive measures to ensure equal enjoyment of rights (Council of Europe, 2021). It is emphasized that the success of efforts to overcome the current crisis depends most on the involvement of the social partners and civil society in the planning, implementation and evaluation of these efforts.

The main areas of social policy are:

- ensuring economic security;

- protection of employees and the appropriate level of remuneration;

- providing a person from birth to old age with normal conditions for life and development;

- ensuring effective protection of the population: improving the quality of social protection; health, culture, housing, demographic improvement;

- creating the necessary conditions for the functioning of the family.

Each of these areas has been negatively affected by COVID-19 and therefore requires timely government intervention.

All measures aimed at ensuring a minimum level of social protection are primarily aimed at obtaining a sufficient income, for example, in the event of illness, unemployment or old age. In addition to the economic goal of providing income, state social policy is aimed at maintaining social equality in society.

From the economic point of view, the state's activities in the field of social policy can be divided into the provision of compulsory social insurance, which includes health care, pensions, unemployment insurance, long-term care and accident insurance, as well as measures of state redistribution in case of special burden, for example, by paying child, parent and housing benefits, as well as unemployment benefits. 
On December 4, 2020, The Law of Ukraine "On Social Support of Insured Persons and Business Entities for the Period of Restrictive AntiEpidemic Measures Introduced to Prevent the Spread of Acute Respiratory Disease COVID-19 Caused by SARS-CoV-2 Coronavirus in Ukraine" was adopted (Law No. 107-IX, 2020).

This law defined three forms of implementation of social support:

- one-time financial assistance to insured persons;

- one-time financial assistance to business entities;

- one-time compensation to business entities.

All forms of social support involve a one-time payment from the state. It should be noted that on April 9, 2021, The Law of Ukraine "On Assistance to Insured Persons for the Period of Restrictive Anti-Epidemic Measures Introduced to Prevent the Spread of Acute Respiratory Disease COVID-19 Caused by SARS-CoV-2 Coronavirus" suspended the previous Law of Ukraine on providing social support in the form of one-time assistance to insured persons, that is, the first of the aforementioned forms of social support. Instead, assistance was introduced to insured persons - payments from the State Budget of Ukraine and local budgets in connection with the loss of wages by employees of economic entities whose work was temporarily suspended due to the introduction in 2021 of restrictive anti-epidemic measures and due to the partial loss of the income of natural persons - entrepreneurs whose economic activity is temporarily suspended due to the introduction of additional restrictive anti-epidemic measures related to the spread of coronavirus disease (COVID-19) (Law No. 1358-IX, 2021). Accordingly, the established amount of such assistance at the expense of the State Budget of Ukraine is UAH 8,000, and at the expense of the local budget - in the amount determined by the decision of the local government. According to the data published by the Pension Fund of Ukraine, as of June 7, 2021, the Pension Fund of Ukraine financed UAH 2,719.5 million. (Pension Fund of Ukraine, 2021). To ensure such payments in 2021, the Ministry of Social Policy was allocated funds in the amount of UAH $1,400,000$ from the special fund of the state budget of Ukraine (Resolution № 328, 2021).

An insured person who meets the requirements established by the above Law of Ukraine has the right to apply for assistance within 30 days from the date of introduction of additional restrictive anti-epidemic measures related to the spread of coronavirus in the relevant administrativeterritorial unit.

It is worth noting the significant progress in the digitalisation of public services, which was provoked by the COVID-19 pandemic, as filling out and submitting an application is possible only in electronic form using the Unified State Web Portal of electronic services. In recent years, the latest technologies have caused a huge wave of changes in the activities of many spheres of public life around the world (Latkovska, Marushchak, \& Oleksiy, 2021). The prevalence of information and communication technologies in the modern world makes it virtually impossible to lead a daily life without them. Today, it is difficult to name a sphere of public life that would not be affected by digitalisation, which is the conversion of data into digital format using technology. Adaptation of digitalisation is very important, in particular, for the banking sector (Marushchak, 2021).

In general, the COVID-19 pandemic crisis has had a positive impact on digitalisation for all countries. The reason for this is that measures to curb the spread of the pandemic have forced governments and businesses to redirect much of their activities and services online. Governments have begun to use digital technologies to improve the quality and accessibility of services, streamline administrative procedures, and improve the effectiveness of social protection programs. Companies are also increasingly implementing measures aimed at continuing their activities by studying business models online and improving the remote working opportunities of their employees.

The second form of social support is one-time financial assistance to economic entities - a onetime payment of the state to economic entities to preserve jobs in order to pay employees of the economic entity one-time financial assistance during the implementation of restrictive antiepidemic measures related to coronavirus diseases.

Unlike the previous form of social support, the amount of one-time financial assistance to businesses is not fixed and is determined in proportion to the reduced working hours of the employee. The maximum amount of such assistance may not exceed UAH 8,000 per employee. Supervisory powers in this area are performed by the employment centre, which controls the targeted use of funds transferred to the entity for payment of one-time financial 


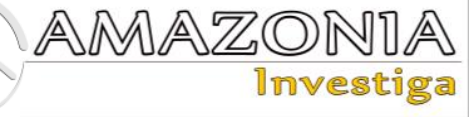

assistance to employees by conducting an inspection within 180 calendar days after payment of such assistance to the entity (Resolution № 1231, 2020).

Emergency measures by governments, including job closures, have often been implemented on the advice of health authorities. Re-creation of jobs is not an easy task and should be carried out considering not only the general recommendations of health authorities, but also standards and procedures of labour protection. This is an important condition, but the recommendations of public health authorities in many countries do not pay enough attention to these standards (Lukyanova, \& Zaytseva, 2021).

The third form of social support is a one-time compensation to economic entities - a one-time payment of the state to economic entities that are legal entities, in order to reimburse the costs incurred for the payment of a single contribution to compulsory state social insurance (Law No. 1071-IX, 2020). Thus, business entities are entitled to receive one-time compensation if, as of October 31, 2020, their main type of economic activity belonged to the List of types of economic activity approved by the legislation of Ukraine. The amount of one-time compensation of the business entity is calculated as the average value of the amounts paid by the business entity of the single contribution to the obligatory state social insurance for ten months. The list of economic activities is established by a resolution of the Cabinet of Ministers of Ukraine dated December 9, 2020 № 1236 “On Quarantine and Introduction of Restrictive Anti-Epidemic Measures to Prevent the Spread of Acute Respiratory Disease COVID-19 Caused by SARS-CoV-2 Coronavirus in Ukraine". They include retail trade in textiles, electrical goods, books, sports equipment, games and toys, clothing, footwear and leather goods, watches and jewellery, film screenings, theatre and concert activities, etc.

Another social benefit, the amount of which increased under quarantine, was unemployment benefits. For the period of quarantine, the Fund of Compulsory State Social Insurance of Ukraine in the Event of Unemployment has increased the minimum amount of unemployment benefits from UAH 650 to UAH 1,000.

Addressing unemployment is currently one of the main challenges facing the government. The impact of the COVID-19 pandemic on the development of the situation on the Ukrainian labour market leads to a direct and indirect reduction in the involvement of labour in economic activities. This situation is a consequence of the temporary ban or restriction of many economic activities in Ukraine. In addition, there was a sharp change in demand for various goods and services of domestic and foreign enterprises.

It is no secret that many business owners, institutions, and organizations lost significant income during the pandemic, and workers lost not only income but also work. Therefore, it is necessary to analyse the regulatory framework of the institute of dismissal at the initiative of the employer (Chupryna, Murtishcheva, Kravtsov, Poproshaieva, \& Zakomorna, 2021). One of the consequences of the spread of COVID-19 was significant changes in the labour market. While much attention is paid to the regulation of labour relations, a number of mechanisms are being developed to resolve conflicts between employees and employers, to protect their legal rights, because every employee must be sure that the risks associated with his work are minimized (Kudriavtsev, Kotova, \& Arsentieva, 2021).

One way to address such risks is to legislate for the ability of employees to perform their duties remotely. Yes, we do not yet know exactly how COVID-19 will change our world in the long run, but one thing is clear today: social distancing and social isolation are needed to slow the spread of the virus. This issue became especially relevant with the beginning of the epidemic.

Thus, it can be argued about the emergence of a new type of workplace relations, which differ in their implementation from the usual. Such relations are still an exception. This is partly due to the lack of reliable experience, and partly due to the lack of legal regulation, which causes a number of legal problems.

Today, the basic document in the field of legal regulation of remote work is the International Labour Organisation's Homework Convention № 177 adopted on June 20, 1996. It should be clarified that Ukraine has not yet ratified it. Article 3 of this Convention provides that each Member which has ratified this Convention recognises, conducts and periodically reviews national policies in the field of work from home aimed at improving the situation of home-based workers (The Homework Convention C177, 1996). The member does it in consultation with the most representative organizations of employers and workers and dealing with homebased workers, and with employers' 
organizations that provide work to home-based workers, where such organisations exist.

The term "home-based work" itself is defined by the Convention as work performed by a homebased worker under three conditions:

- work is performed at the place of residence, or in other premises that do not belong to the production premises of the employer;

- $\quad$ work is performed for a fee;

- the purpose of the work is the production of goods or services in accordance with the instructions of the employer and does not depend on who provides the equipment, materials or other resources used.

During 2020-2021 The Verkhovna Rada of Ukraine has made some changes in the current domestic legislation in the field of home-based work. In fact, the parliament has legalised the changes that have existed in the Ukrainian labour market for some time. But they became apparent during quarantine, when a significant number of people moved to work from home. Relevant proposals for the regulation of remote work take into account some provisions of acts of the International Labour Organization on homebased and remote work. And although these international legal acts have not yet been ratified by our country, their norms can serve as a guide for the legislator (Silchenko, \& Serbina, 2021).

In particular, the Code of Labour Laws of Ukraine in 2021 was supplemented by Article 602 "Remote Work". Thus, there is a legal definition according to which remote work is a form of work organisation in which work is performed by an employee outside the work premises or territory of the owner or his authorized body, anywhere chosen by the employee and using information and communication technologies (Law No. 322-VIII, 1971).

A necessary aspect of home-based work is the provision of persons working remotely with all social and labour guarantees provided by labour legislation. Therefore, an important point was the establishment of the Standard form of employment contract for telecommuting, which is approved by the Central Executive Body, which ensures the formation of state policy in the field of labour relations.

Part 8 of Article 179 became an innovation in the Labour Code of Ukraine. According to it, persons on childcare leave may, if they wish, work parttime or at home.
More and more world-renowned companies are supporting the idea of working from home and flexible schedules. This is facilitated by new technologies that allow you to conduct virtual video calls. Even now, according to statistics, the percentage of employees working remotely is constantly growing, as are the offers of such work.

There is a tendency to increase remote labour in the market. Therefore, remote work will soon become a reality, and is likely to be implemented as a combination of old norms and new norms established by the COVID-19 regulatory policy (Buchanan, Aslaner, Adelstein, MacKenzie, Wold, \& Gorr, 2021).

At the same time, the COVID pandemic has shown that many organizations, including governments, were unprepared to address unexpected IT and service challenges. In the future, in the event of any other crisis, which is inevitable due to climate change - floods, droughts and fires, organisations need to seriously plan and organise staffing and service delivery through IT systems (Afriantyal, Artatanaya, \& Burgessc, 2021).

Another significant innovation in 2021 in the field of social support was the program of the President of Ukraine "e-Aid" aimed at supporting small and medium-sized businesses affected by the pandemic and stimulating the vaccination process. It is expected that by the end of 2021, 8 million citizens will apply for a payment of one thousand hryvnias. To this end, the Parliament of Ukraine approved changes to the budget and pledged UAH 8 billion for payments to vaccinated citizens.

The legal basis for the provision of social support in this way was the Law of Ukraine "On the peculiarities of the provision of public (electronic public) services" from 15.07.2021. The law established the legal definition of electronic public service - a service provided by public authorities, local governments, enterprises, institutions, organizations under their management, including administrative services (including automatic), which is provided with using information and telecommunication systems on the basis of an application (request) submitted in electronic form using information and telecommunication systems (including using the Unified State Web Portal of electronic services), or without submitting such an application (request) (Law of Ukraine No. 1689IX, 2021). 


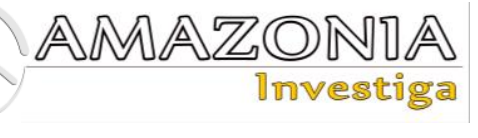

In addition to those outlined above, in general, a whole range of measures has been implemented since 2020 to support the population and business in Ukraine. In case of violation of tax legislation in the period from March 1 to May 31, 2020, no fines were applied, but this rule did not apply to VAT, excise tax and rent. The deadline for submitting the annual income tax return was extended by two months until July 1, 2020. In addition, the parliament suspended the requirement to pay the tax on commercial real estate and land, defining quarantine in connection with COVID-19 as a force majeure under legal agreements. Tax audits at enterprises were also suspended.

Tenants were also temporarily exempted from payments for renting facilities that were not used during the quarantine period. However, the legislative changes exempted the tenant from paying rent not for the period of quarantine or in connection with its introduction, but only if the introduction of quarantine led to the impossibility of using the leased object.

The current situation in Ukraine has a negative impact on relations with the International Monetary Fund (IMF), and they risk further complicating the economic picture in Ukraine. In 2021, Ukraine expected to receive the second tranche of $\$ 2.2$ billion from the IMF under the Stand-by Arrangement program worth \$5 billion, approved in June 2020. However, the last negotiations with the IMF ended in February 2021 with no forecasts as to when the next tranche will be issued. The IMF expressed deep concern over issues such as corruption, gas prices and the Constitutional Court's crisis, and called for structural reforms in these areas, as agreed in previous agreements. There is a risk of insolvency if Ukraine continues to receive no IMF financial support. In such a scenario, even significant issues of international Eurobonds may not be enough to maintain financial stability (OECD report, 2020).

\section{Conclusions}

Social human rights should be seen as the category of rights most affected by the coronavirus pandemic. This has been affected by many of the limitations associated with COVID19. Ukraine, like several other countries, has learned from the current situation and is trying to minimise the impact of new restrictions on human rights. Undoubtedly, it is extremely important to pay attention to the most vulnerable groups of the population - the elderly, the disabled. Therefore, it is natural that most of the social support measures taken in the midst of the pandemic were aimed at the most economically vulnerable categories of citizens. A large part of the population has become the object of social support for citizens, and social protection takes place in many areas that shape our daily lives.

In its statement, the European Committee of Social Rights draws attention to the rights set out in the European Social Charter, which have been particularly affected by the coronavirus crisis: rights related to work and employment, the right to social security and protection against poverty and social exclusion, the right to housing and education. States parties must ensure that measures taken against the crisis, including economic and social policies, do not lead to direct or indirect discrimination in the enjoyment of social rights.

In connection with the coronavirus pandemic, the government has implemented measures in various areas of domestic policy - financial, monetary and social. It can be said that all of them were emergency measures, as they were carried out under extraordinary circumstances. Decisions and actions aimed at their implementation include a range of tasks such as maintaining business, supporting employment, social protection, and public health.

Social support of citizens in this period can be considered in two aspects, as direct and indirect.

Direct social support is a set of measures taken by the government to ensure the implementation of social rights of citizens by increasing the amount of social benefits; providing subsidies, soft loans; deferral of taxes and other mandatory payments; facilitating the conditions for receiving insurance benefits.

Indirect social support of citizens should include measures taken by the government to curb unemployment, support business, and so on. For example, government promotion of non-standard forms and conditions of employment, financial and tax-credit mechanisms targeted at the most affected industries, small and medium-sized businesses.

From an economic point of view, the state's activities in the field of social policy can be divided into the provision of compulsory social insurance (which includes health care, pensions, unemployment insurance, long-term care and accident insurance), as well as state redistribution measures in case of special burden, for example, by paying child benefits, unemployment benefits. 
Over the past two years, Ukraine has taken a decisive step towards overcoming the pandemic crisis, which has led to inevitable changes in many areas. First of all, the changes affected the legislation, which became necessary because in the conditions of COVID-19 the legal regulation of relations in the state and society did not correspond to the actual state of affairs and did not provide a legal opportunity to help improve the situation.

The main means of social policy are benefits and payments aimed at social support. Changes have also taken place in this area, in particular, the state has introduced three forms of social support: one-time financial assistance to insured persons; one-time financial assistance to business entities; one-time compensation to business entities.

It is necessary to note the changes in the field of digitalisation, which are positive in nature, and which were caused by the pandemic. In this area, the state has gained new heights and significantly improved the state of digitalisation of public services. Thus, from now on, even while selfisolated, a person can use public services through the online services "Diia" and "e-Aid".

In conclusion, it is worth noting that the longterm consequences of the COVID-19 pandemic are not yet visible. It is extremely difficult to predict the future situation, as most of the measures taken in the implementation of social policy directly depend on the state of the economy in the country, which, in turn, depends on the course of the pandemic. But today, we can say that the state is not left out and is trying to improve the situation.

\section{Bibliographic references}

Afriantyal, T., Artatanaya, G., \& Burgessc, J. (2021). Working from home effectiveness during Covid-19: Evidence from university staff in Indonesia. Asia Pacific Management Review, 27(1), 50-57. DOI: 10.1016/j.apmrv.2021.05.002

Buchanan, N., Aslaner, D., Adelstein, J., MacKenzie, D., Wold, L., \& Gorr, M. (2021). Remote Work During the COVID-19 Pandemic: Making the Best of It. Physiology, 36, 2-4. DOI: 10.1152/physiol.00035.2020

Chupryna, Y., Murtishcheva, A., Kravtsov, D., Poproshaieva, O., \& Zakomorna, K. (2021). Constitutional Guarantees of The Right to Work Due to the COVID-19 Pandemic. Amazonia Investiga, 10(41), 199-210. DOI: https://doi.org/10.34069/AI/2021.41.05.20
Council of Europe (2021). Statement on COVID19 and Social Rights. Retrieved from https://rm.coe.int/statement-of-the-ecsr-oncovid-19-and-social-rights/1680a230ca

Holosnichenko, D. I. (2020). Social Security of Citizens in The Conditions of Coronavirus. Legal Life of Modern Ukraine, 2, 162-165. (In Ukranian)

Kudriavtsev I., Kotova L., \& Arsentieva O. (2021). Covid Pandemic and Amendments to Employment Law in Ukraine and Europe. Amazonia Investiga, 10 (39), 178-185. DOI: https://doi.org/10.34069/AI/2021.39.03.17

Latkovska, T., Marushchak, A., \& Oleksiy, U. (2021). Legal And Theoretical Problems of Defining Internet Banking in Ukraine. Financial And Credit Activities: Problems of Theory and Practice, 1(36), 27-34. DOI: https://doi.org/10.18371/fcaptp.v1i36.22760 8

Law No. 322-VIII/1971. Labour Code of Ukraine, The Verkhovna Rada of the USSR, dated 10.12.1971 Retrieved from https://zakon.rada.gov.ua/laws/show/32208\#Text

Law of Ukraine No. 1071-IX. "On Social Support of Insured Persons and Business Entities for the Period of Restrictive AntiEpidemic Measures Introduced to Prevent the Spread of Acute Respiratory Disease COVID-19 Caused by SARS-CoV-2 Coronavirus in Ukraine", Verkhovna Rada of Ukraine, dated 04.12.2020. Retrieved from https://zakon.rada.gov.ua/laws/show/107120\#Text

Law of Ukraine No. 1358-IX. On Providing Assistance to Insured Persons During the Period of Restrictive Anti-Epidemic Measures Introduced to Prevent the Spread of Acute Respiratory Disease COVID-19 Caused by Coronavirus SARS-CoV-2, Verkhovna Rada of Ukraine, dated 30.03.2021. Retrieved from https://zakon.rada.gov.ua/laws/show/135820\#n60

Law of Ukraine No. 1689-IX. On The Peculiarities of Providing Public (Electronic Public) Services, Verkhovna Rada of Ukraine, dated 15.07.2021. Retrieved from https://zakon.rada.gov.ua/laws/show/168920\#Text

Lukyanova, N.L., \& Zaytseva, O.O. (2021). The coronavirus pandemic: legal mechanisms to protect the labor and social rights of workers. Federación de Sindicatos de Ucrania. Retrieved from: http://rv.dsp.gov.ua/wpcontent/uploads/2021/02/lhsi_pandemya_kor onavrusu.pdf 


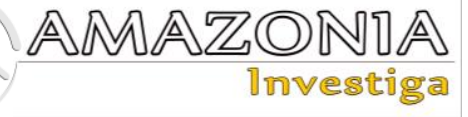

Marushchak, A. (2021). Supervisory Powers of The World's Central Banks and Some Aspects of Their Digital Transformation. Financial Law in The Conditions of Digital Transformation: Collective Monograph. Chernivtsi: Technodruk, 418 p. DOI: https://doi.org/10.32837/11300.15123

OECD report. (2020). The Covid-19 crisis in Ukraine. Retrieved from https://www.oecd.org/eurasia/competitivene ss-programme/eastern-partners/COVID-19CRISIS-IN-UKRAINE.pdf

Pension Fund of Ukraine (2021) The Pension Fund of Ukraine continues to finance assistance to insured persons in the amount of UAH 8,000, dated 07.06.2021. Retrieved from https://www.pfu.gov.ua/2140829pensijnyj-fond-ukrayiny-prodovzhuyefinansuvannya-dopomogy-zastrahovanymosobam-v-rozmiri-8-000-gryven-6/

Resolution № 1231. Some issues of implementation of Article 3 of the Law of Ukraine "On Social Support of Insured Persons and Business Entities for the Period of Restrictive Anti-Epidemic Measures Introduced to Prevent the Spread of Acute Respiratory Disease COVID-19 caused by the SARS-CoV-2 coronavirus", Cabinet of Ministers of Ukraine dated 09.12.2020. Retrieved from https://zakon.rada.gov.ua/laws/show/12312020-\%D0\%BF\#Text

Resolution № 1236. On the establishment of quarantine and the introduction of restrictive anti-epidemic measures to prevent the spread of acute respiratory disease COVID-19 caused by the SARS-CoV-2 coronavirus in
Ukraine, Cabinet of Ministers of Ukraine, dated 09.12.2020. Retrieved from https://zakon.rada.gov.ua/laws/show/12362020-\%D0\%BF\#Text

Resolution № 328. On additional measures of social support of insured persons for the period of restrictive anti-epidemic measures introduced to prevent the spread of acute respiratory disease COVID-19 caused by the SARS-CoV-2 coronavirus in Ukraine, Cabinet of Ministers of Ukraine, dated 07.04.2021. Retrieved from https://zakon.rada.gov.ua/laws/show/3282021-\%D0\%BF\#Text

Silchenko, S., \& Serbina, D. (2021). Remote Work: Current State and Prospects of the Legal Regulation Development. Entrepreneurship, Economy and Law, 1, 93-99. DOI: https://doi.org/10.32849/26635313/2021.1.16

The Homework Convention C177. International Labour Organization, dated 20.06.1996. Retrieved from https://zakon.rada.gov.ua/laws/show/993_32 7\#Text

UNICEF (2020) Consensus forecast "Ukraine: the impact of COVID-19 on the economy and society" (vision of post-pandemic development in 2020-2024 through the eyes of experts and youth), Department of Strategic Planning and Macroeconomic Forecasting of the Ministry of Economic Development, Trade and Agriculture, dated August 2020. Retrieved from https://www.unicef.org/ukraine/documents/c onsensus-report 